\title{
Measuring the Impact of Higher Capital Requirement to Bank Lending Rate and Credit Risk: The Case of Southeast Asian Countries
}

\author{
Winda F.K. Pratiwi' ${ }^{1}$, Sigit S. Wibowo ${ }^{1 *}$ \\ ${ }^{1}$ Faculty of Economics and Business, Universitas Indonesia \\ Email: sigit.sw@ui.ac.id
}

\begin{abstract}
This study discusses the impact of increasing bank capital against lending interest rate, amount of loans, and banks' credit risk exposure. The study utilized panel data from 18 top banks in 5 Southeast Asian countries during the period of 2008-2015. The findings show that there is no significant relationship between capital increase and lending interest rate in Southeast Asia. This is due to lending interest rate movement was driven mostly from banks' cost structure, rather than capital charge. Although lending interest rate has significant relationship with amount of loans, there are no transmitted impact of the capital increase to the economy. The study also found that bank capital level has positive relationship with credit risk which indicates that level of bank capital serves as a buffer against credit risk.
\end{abstract}

Type of Paper: Empirical paper

Keyword: Basel III Capital; credit risk; lending rate.

\section{Introduction}

The changes in the financial system especially in the banking industry are mainly influenced by regulatory changes in recent decades (Hellman et al., 2000). There are at least three types of regulatory changes for the past three decades. The first change focuses on the absence of control within bank's risk management process in line with the increasing complexity of financial transactions. Then, the second change focuses on the regulation of bank's interest rate and investment choice. The third change focuses on increasing the bank's capital requirements, which are set out in the Basel regulations.

In 2011, the Bank for International Settlement (BIS) issued Basel III, which the main purpose of is to strengthen the bank's capital structure and to maintain liquidity. It also proposes new measurements of risks and increase the resilience of the global banking industry. This policy is implemented to improve both the quality and quantity of regulatory capital and expand the scope of the risks of the capital framework (Bank for International Settlements, 2011).

In line with these regulations, central banks in the Southeast Asia region have adapted the new 


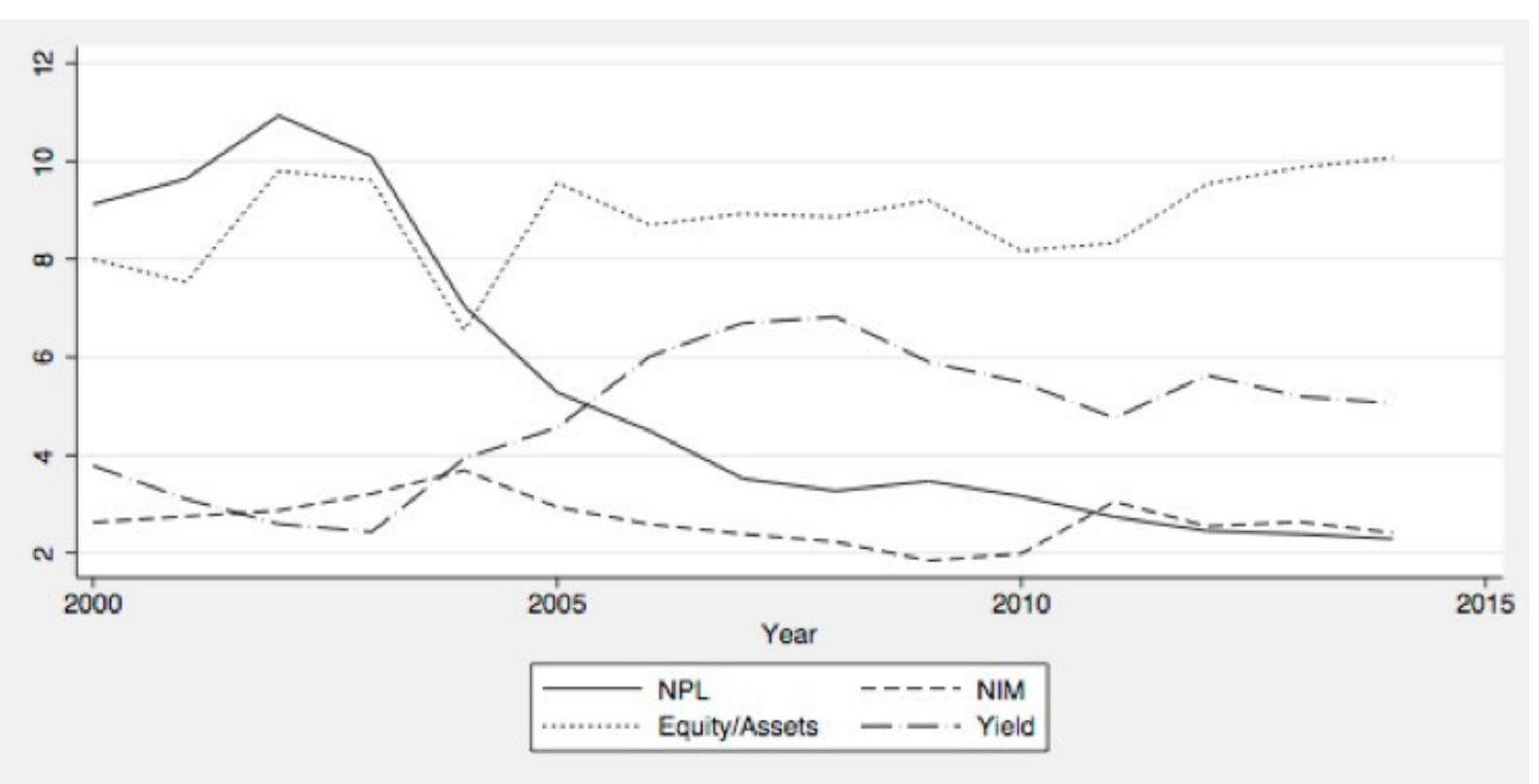

Source: authors' calculations from Bankscope.

Figure 1. Capital, Yield and NPL Trend in Southeast Asian countries.

framework of the capital increase with new capital regulations. However, the implementation of the capital increase in accordance with Basel III is reaping a debate. Some may argue that high levels of capital will increase the strength of banks and lowered the risk of bankruptcy (Cosimano and Hakura, 2011). However, capital increase requires a significant cost. A higher capital will increase the price (interest rate) of loans and impede credit growth, which will slow down the process of recovery in the economy. Others may argue that higher level of capital will likely lead to risk-taking behavior is higher. This is based on the idea that the higher capital requirements will reduce bank revenue stream. In the end, along with high competition in the industry, banks tend to make decisions that lead to speculative and create unstable financial system (Hellman et al., 2000).

This research aims to provide a deep understanding about the impact of higher capital requirement in the banking industry for Southeast Asia. The analysis of higher capital impact serves as the underlying process of identifying interest sensitivity of the Southeast Asian banks with respect to regulatory changes in the banking industry. Figure 1 provides a general overview of bank capital movement represented by the ratio of equity to total assets associated with the movement of NPLs as approach to measure credit risk and loan interest rates. The movement of interest rates was in line with capital movements, whilst the NPLs tend to move in the opposite direction. This means there is a certain pattern in the determination of bank's lending rate in ASEAN countries which may be affected by changes in minimum regulatory capital and asset quality.

The results provide empirical evidence that the decision to increase capital in the ASEAN-5 is significantly influenced by level of capital on the previous period and their credit risk. Whilst level of capital increase does not significantly affect the movement of lending rate in ASEAN-5, of which more caused by the movement of its cost components (deposits rate, other costs rate, and the required rate of return). The rest of this paper is described as follows. Section 2 provides existing literature related to this paper. Section 3 describes methodology used in this paper. Section 4 discusses the empirical findings. Section 5 concludes the study. 


\section{Literature Review}

Several studies on the consequences of tighter capital regulations based on Basel III tried to identify the impact of these regulations to the economy by using changes in interest rates and the number of loans disbursed as an indicator of the economic downturn. As published in BIS report, Long-term Economic Impact (LEI) Working Group research concluded that each percent change in the capital structure using the Total Capital ratio Equity (TCE) to Risk Weighted Assets (RWA) will require lending rate increases by 13 basis points (Bank for International Settlements, 2011). Another report by BIS finds the numbers sensitivity changes interest rate at 15.5 basis points and a decrease of $1.4 \%$ in loans at 35 th quarter after the capital regulations were first implemented (Macroeconomic Assessment Group, 2010).

A study by IMF finds that the required increase of lending interest rate by 120 basis points gradually in 2 years for each $2 \%$ increase in capital adequacy ratio (Roger and Vlcek, 2011). This is in line with another study conducted by IMF which found that every $1.3 \%$ increase in capital ratios will require increases in interest rates by 16 basis points, which are then led loans reduced by $1.3 \%$ in the long term (Cosimano and Hakura, 2011). From this report, another study discovered that an increase in regulatory capital by $1.3 \%$ according to Basel III will cause a decrease in loans by $4.97 \%$ in countries with crisis and $18.67 \%$ in countries that are not in crisis (Gavalas, 2015). While other research finds that increasing the capital ratio of $2.92 \%$ will trigger increases in lending interest rates of 54.9 basis points (Sútorová and Téply, 2013).

In Indonesia, CAR has a statistically positive effect on the banks profitability in Indonesia and credit risk represented by the non-performing loan (NPL) requires banks to increase loan provision which then triggers a rise in interest rates (Raharjo et al., 2014). Prudent lending would have a positive effect on the bank NIM (Berrios, 2013). However, there is no specific research about Southeast Asian economies regarding this subject. Thus, this reserve will serve as predictive report regarding the impact of regulatory capital increase according to Basel III that will begin in 2016 towards banking industry and Southeast Asian economies. With regards to existing literature, this research also studies its impacts on credit risk that may arise because of capital changes in Southeast Asian countries.

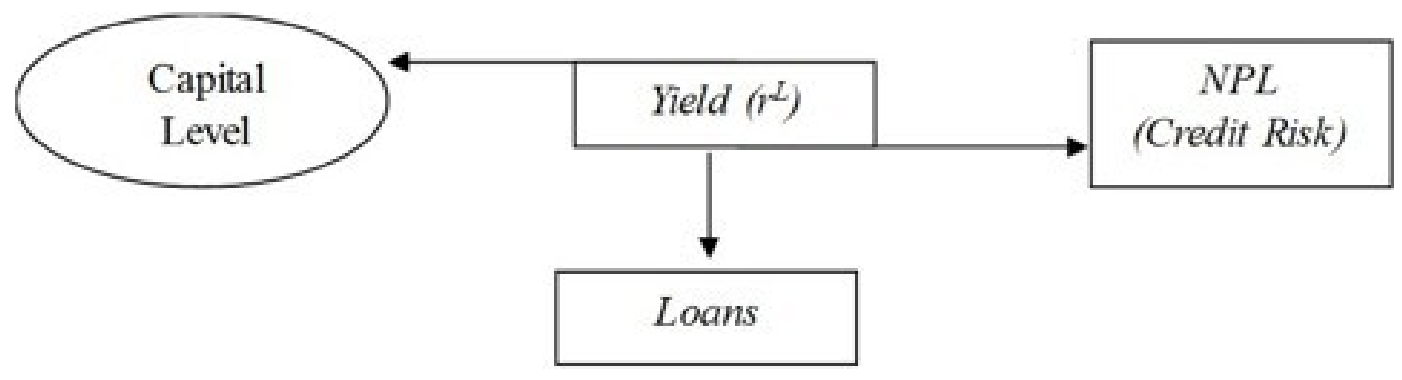

Source: authors' compilation.

Figure 2. Research Framework. 


\section{Research Methodology}

The study utilized models in previous studies (Gavalas, 2015 and Sútorová and Téply, 2013) and put it to Southeast Asian context, using framework on Figure 2. The panel data approach was employed to examine the banking data. This study used several data sources such as: (1). Financial performance data of Southeast Asian banks which are secondary data from database Bankscope issued by Bureau van Dijk and Reuters database; (2) The bank's annual report are obtained from the website of each bank; (3) macroeconomic data are obtained from World Bank and each country central bank's website.

Using model from Gavalas (2015) and Sútorová and Téply (2013) for level of capital, lending rate model and loans model specified as follow:

$$
\begin{aligned}
& \frac{K}{A}= \alpha_{0}+\alpha_{1}\left(\frac{\Delta K}{A}\right)_{t-1}+\alpha_{1}\left(\frac{K}{A}\right)_{t-1}\left(\frac{\Delta K}{A}\right)_{t-1}+\alpha_{3} r^{D}+\alpha_{4}\left(\frac{K}{A}\right)_{t-1} r^{D}+\alpha_{5} C_{L}+ \\
& \alpha_{6}\left(\frac{K}{A}\right)_{t-1} C_{L}+\alpha_{7} C_{D}+\alpha_{8}\left(\frac{K}{A}\right)_{t-1} C_{D}+\alpha_{8} \ln \text { Assets }+\alpha_{9} \ln \text { Assets }^{2}+\epsilon_{1} \\
& r^{L}= \beta_{0}+\beta_{1}\left(\frac{\Delta K}{A}\right)+\beta_{2} r^{D}+\beta_{3} C_{L}+\beta_{4} C_{D}+\beta_{5} r^{K}+\beta_{6} \ln \text { Assets }+\beta_{7} G D P+ \\
& \beta_{8} I N F+\beta_{9} r^{I}+\epsilon_{2} \\
& \ln \text { Loans }=\gamma_{0}+\gamma_{1} \ln r^{D}+\gamma_{2} G D P+\gamma_{3} I N F+\gamma_{4} r^{I}+\gamma_{5} \ln \text { Assets }+\epsilon_{3}
\end{aligned}
$$

where $K / A$ denotes equity/assets ratio on period $t, r^{L}$ denotes bank's lending rate, $\ln$ Loans denotes natural logarithm of total loans, $(K / A)_{t-1}$ denotes equity/assets ratio on period $t-1$, $r^{D}$ denotes bank's cost of fund, $C_{L}$ denotes non-performing loans, $C_{D}$ denotes other cost ratio, $r^{K}$ denotes cost of capital, ln Assets denotes natural logarithm of total assets, GDP denotes real GDP growth, $I N F$ denotes inflation rate, $r^{I}$ denotes country's policy rate and $\epsilon$ denotes the residual terms. We also use CAR or capital adequacy ratio and Tier 1 capital as a measure for bank capital.

As described in Equation (1), (2), and (3), the level of capital will affect banks' lending rate, then the impacts will be transmitted to loans amount. Hence, the level of capital is also exposed to existing credit risk through the relationship between risk and returns (Hellman et al., 2000). The study utilized information on the period of 2008-2015 due to the fact that there are variations in economic conditions of ASEAN banking on that period. The samples consist of 18 banks, sorted by largest portion of the total assets market share as shown in Figure 3 and descriptive statistics as shown in Table 1. These are:

1. Singapore (3 banks): DBS Group of Singapore, OCBC and UOB.

2. Malaysia (6 banks): Maybank, CIMB Group, Public Bank, RHB Bank, HongLeong Group and AM Bank.

3. Thailand (4 banks): Bangkok Bank, Krung Thai Bank, Siam Commercial Bank and KasikornBank.

4. Indonesia (4 banks): Bank Mandiri, BRI, BCA and BNI.

5. The Philippines (1 bank): BDO Unibank. 
Table 1. Descriptive Statistics.

\begin{tabular}{|c|c|c|c|c|c|}
\hline & Obs. & Mean & Max. & Min. & Std. Dev. \\
\hline \multicolumn{6}{|c|}{ Dependent variables } \\
\hline $\mathrm{K} / \mathrm{A}$ & 576 & $9.68 \%$ & $17.86 \%$ & $4.10 \%$ & $1.92 \%$ \\
\hline CAR & 576 & $15.50 \%$ & $22.14 \%$ & $11.70 \%$ & $1.66 \%$ \\
\hline TIER1 & 576 & $12.45 \%$ & $18.72 \%$ & $7.40 \%$ & $2.26 \%$ \\
\hline $\mathrm{r}^{\mathrm{L}}$ & 576 & $6.61 \%$ & $29.89 \%$ & $0.28 \%$ & $3.48 \%$ \\
\hline ln Loans & 576 & 17.49 & 19.17 & 15.85 & 0.72 \\
\hline \multicolumn{6}{|c|}{ Independent variables } \\
\hline$(\Delta \mathrm{K} / \mathrm{A})_{(\mathrm{t}-1)}$ & 576 & $-0.08 \%$ & $1.15 \%$ & $-1.10 \%$ & $0.52 \%$ \\
\hline $\mathrm{r}^{\mathrm{D}}$ & 576 & $2.14 \%$ & $5.54 \%$ & $0.54 \%$ & $1.04 \%$ \\
\hline $\mathrm{C}_{\mathrm{L}}$ & 576 & $2.74 \%$ & $10.17 \%$ & $0.29 \%$ & $1.77 \%$ \\
\hline $\mathrm{C}_{\mathrm{D}}$ & 576 & $1.52 \%$ & $8.41 \%$ & $0.00 \%$ & $0.96 \%$ \\
\hline $\mathrm{r}^{\mathrm{K}}$ & 576 & $5.88 \%$ & $23.86 \%$ & $-3.60 \%$ & $2.73 \%$ \\
\hline ln Assets & 576 & 17.98 & 19.63 & 16.52 & 0.71 \\
\hline \multicolumn{6}{|c|}{ Macroeconomic variables } \\
\hline GDP & 576 & $4.34 \%$ & $19.30 \%$ & $-8.90 \%$ & $3.90 \%$ \\
\hline INF & 576 & $3.37 \%$ & $12.14 \%$ & $-4.03 \%$ & $2.76 \%$ \\
\hline $\mathrm{r}^{\mathrm{I}}$ & 576 & $3.35 \%$ & $9.25 \%$ & $0.19 \%$ & $2.27 \%$ \\
\hline
\end{tabular}

Note: $K / A$ denotes equity/assets ratio on period $t, C A R$ denotes capital adequacy ratio, TIER1 denotes Tier-1 capital ratio, $r^{L}$ denotes bank's lending rate, $\ln$ Loans denotes natural logarithm of total loans, $(\Delta K / A)_{t-1}$ denotes equity/assets ratio on period $t-1, r^{D}$ denotes bank's cost of fund, $C_{L}$ denotes non-performing loans, $C_{D}$ denotes other cost ratio, $r^{K}$ denotes cost of capital (ROE), ln Assets denotes natural logarithm of Total Assets, GDP denotes real GDP growth, INF denotes inflation rate, and $r^{I}$ denotes country's policy rate. Source: authors' calculations.

Table 2. Correlation Matrix

\begin{tabular}{|c|c|c|c|c|c|c|c|c|c|c|c|c|c|c|}
\hline & $K / A$ & $C A R$ & TIER 1 & $r^{I}$ & $\ln$ Loans & $\left(\frac{\Delta K}{A}\right)_{t-1}$ & $r^{D}$ & $C_{L}$ & $C_{D}$ & $r^{K}$ & $I N F$ & $G D P$ & $\ln$ Assets & $r^{L}$ \\
\hline $\mathrm{K} / \mathrm{A}$ & 1 & & & & & & & & & & & & & \\
\hline CAR & 0.53 & 1 & & & & & & & & & & & & \\
\hline TIER1 & 0.266 & 0.775 & 1 & & & & & & & & & & & \\
\hline $\mathrm{r}^{\mathrm{I}}$ & 0.142 & 0.025 & 0.222 & 1 & & & & & & & & & & \\
\hline ln Loans & -0.078 & 0.194 & 0.129 & -0.627 & 1 & & & & & & & & & \\
\hline$(\Delta \mathrm{K} / \mathrm{A})_{(\mathrm{t}-1)}$ & 0.166 & 0.108 & 0.076 & 0.055 & -0.039 & 1 & & & & & & & & \\
\hline $\mathrm{r}^{\mathrm{D}}$ & -0.076 & -0.129 & 0.01 & 0.759 & -0.447 & 0.025 & 1 & & & & & & & \\
\hline $\mathrm{C}_{\mathrm{L}}$ & -0.006 & -0.196 & -0.339 & 0.088 & -0.33 & 0.006 & 0.183 & 1 & & & & & & \\
\hline $\mathrm{C}_{\mathrm{D}}$ & 0.247 & 0.115 & 0.214 & 0.469 & -0.426 & -0.005 & 0.234 & 0.207 & 1 & & & & & \\
\hline $\mathrm{r}^{\mathrm{K}}$ & -0.022 & -0.094 & 0.066 & 0.503 & -0.458 & -0.007 & 0.266 & -0.141 & 0.271 & 1 & & & & \\
\hline$I N F$ & 0.049 & 0.031 & 0.131 & 0.619 & -0.334 & 0.011 & 0.482 & 0.047 & 0.342 & 0.269 & 1 & & & \\
\hline$G D P$ & -0.009 & 0.126 & 0.145 & 0.196 & -0.055 & 0.011 & 0.078 & -0.076 & 0.025 & 0.185 & 0.269 & 1 & & \\
\hline ln Assets & -0.152 & 0.209 & 0.19 & -0.636 & 0.979 & -0.043 & -0.441 & -0.386 & -0.424 & -0.456 & -0.303 & -0.036 & 1 & \\
\hline $\mathrm{r}^{\mathrm{L}}$ & 0.12 & 0.035 & 0.221 & 0.798 & -0.537 & 0.043 & 0.741 & 0.147 & 0.449 & 0.5 & 0.507 & 0.108 & -0.536 & 1 \\
\hline
\end{tabular}

Note: $K / A$ denotes equity/assets ratio on period $t, C A R$ denotes capital adequacy ratio, TIER 1 denotes Tier-1 capital ratio, $r^{L}$ denotes bank's lending rate, $\ln$ Loans denotes natural logarithm of total loans, $(\Delta K / A)_{t-1}$ denotes equity/assets ratio on period $t-1, r^{D}$ denotes bank's cost of fund, $C_{L}$ denotes non-performing loans, $C_{D}$ denotes other cost ratio, $r^{K}$ denotes cost of capital (ROE), ln Assets denotes natural logarithm of Total Assets, GDP denotes real GDP growth, INF denotes inflation rate, and $r^{I}$ denotes country's policy rate. Source: authors' calculations.

The banks selected as the samples of this study are those in the top 20 Southeast Asian banks rank by total assets (Forbes, 2014). Two Philippines banks (Metrobank Philippines and Bank of Philippines Island) are being excluded because they did not have issued the last quarter of 2015 


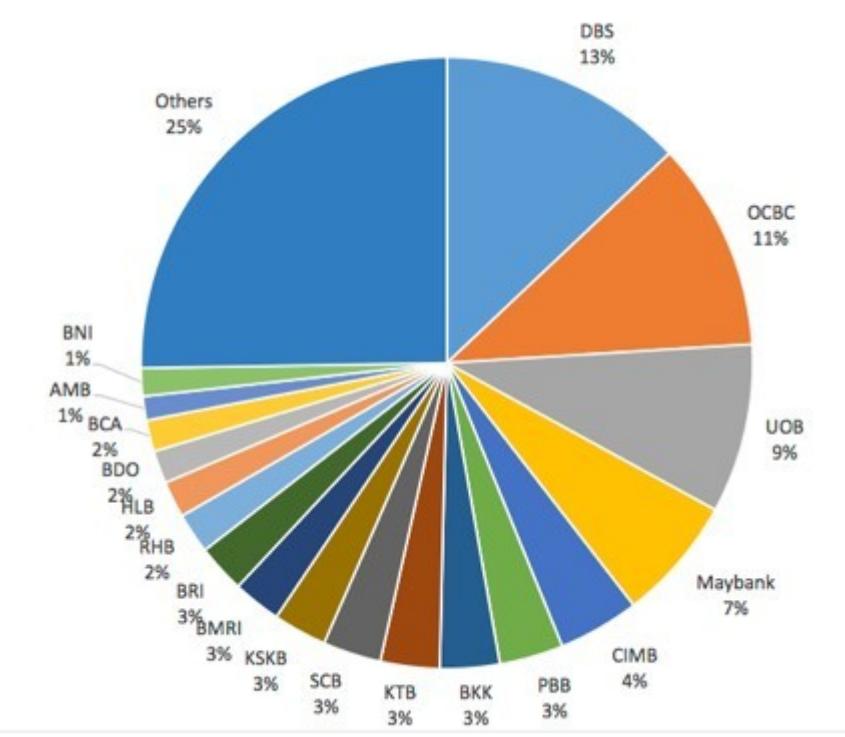

Source: Reuters and each country central bank's website.

Figure 2. Sample bank's market share in Southeast Asian banking industry.

financial report yet. Therefore, this study only covers a sample of fice largest Southeast Asian countries namely Singapore, Malaysia, Indonesia, Thailand, and the Philippines (hereinafter referred to as ASEAN-5). Based on the data collected and processed from central bank of ASEAN-5, as of December 2015 total assets amounted to USD2,501 billion. Whereas in the same period the total assets of 18 sample bank amounted USD1,869 billion, thus concluded that 18 sample banks in this study have represented $74.7 \%$ of total assets in ASEAN-5.

\section{Empirical Findings}

Using random effect model, Table 3 and 4 provide the estimation results of three models use in this research. Variables that significantly affect level of capital in banks are capital ratio in the previous period and NPL as a proxy for credit risk. Barajas et al. (2010) argue that capital option held by the bank is a function of the optimal amount of loans disbursed in the future. With option values, there is a difference between the optimal amount of loans in the future with banks' lending capacity.

Since capital is formed by withhold a portion of the bank's assets, not all the bank fund can be channeled as loans. By the time of optimal number of loans extended in the future increases, banks will increase the capital in order for the future banks have a higher capacity to extend their loans. On the other hand, the declining demand for loans in the future will not provide incentives to banks to hold capital or increase its capital. Therefore, it can be concluded that current level of capital is positively correlated with required levels of capital in the future. On ASEAN-5, the results can be inferred through the variable KA1, CAR1, and TIER1 respectively. This indicates the position of the level of capital in previous period, which has a significant positive relationship ( $\alpha=1 \%$ ) with each dependent variable. An increase in the level of capital by $1 \%$ would raise the level of capital in the future by $1.03 \%$, while slightly smaller coefficient values indicated by type of capital CAR by $0.82 \%$ and Tier 1 by $0.91 \%$ respectively. 
Table 3. Estimation Results

\begin{tabular}{|c|c|c|c|c|c|c|c|c|c|}
\hline \multicolumn{4}{|c|}{ Bank capital } & \multicolumn{4}{|c|}{ Lending rate } & \multicolumn{2}{|c|}{ Loans } \\
\hline & $\mathrm{K} / \mathrm{A}$ & CAR & TIER1 & & $\mathrm{K} / \mathrm{A}$ & CAR & TIER1 & & ln Loans \\
\hline \multirow[t]{2}{*}{ Intercept } & -0.3444 & $-0.5653 * * *$ & $-0.4349 *$ & Intercept & $0.3036^{* * *}$ & $0.3059 * * *$ & $0.3034 * * *$ & Intercept & $-2.7840 * * *$ \\
\hline & $(0.2306)$ & $(0.2588)$ & -0.2429 & & $(0.0742)$ & $(0.0770)$ & -0.0754 & & $(0.7944)$ \\
\hline \multirow[t]{2}{*}{$\mathrm{K} / \mathrm{A} 1$} & $1.0301 * * *$ & $0.8217 * * *$ & $0.9117 * * *$ & $\mathrm{~K} / \mathrm{A} 1$ & -0.0346 & & & $\ln \mathrm{r}^{\mathrm{L}}$ & $-0.1376^{* * *}$ \\
\hline & $(0.0711)$ & $(0.0713)$ & -0.0571 & & $(0.0610)$ & & & & -0.0411 \\
\hline \multirow[t]{2}{*}{ vKA1 } & 0.7922 & $-0.1837 * *$ & $-0.3320 * * *$ & TIER1 & & -0.0155 & & ln Assets & $1.1025^{* * *}$ \\
\hline & $(0.7718)$ & $(0.0752)$ & -0.0993 & & & $(0.0418)$ & & & -0.0454 \\
\hline \multirow[t]{2}{*}{$\mathrm{r}^{\mathrm{D}}$} & -0.0222 & $-0.7996 * *$ & -0.1474 & CAR & & & 0.0013 & GDP & $-0.2649 * * *$ \\
\hline & $(0.2614)$ & $(0.4031)$ & -0.2411 & & & & -0.0487 & & -0.0848 \\
\hline \multirow[t]{2}{*}{$\mathrm{K} / \mathrm{A} 1 \cdot \mathrm{r}^{\mathrm{D}}$} & -0.4579 & $4.9566^{*}$ & 1.4029 & $\mathrm{r}^{\mathrm{D}}$ & $1.0587 * * *$ & $1.0649 * * *$ & $1.0779 * * *$ & INF & 0.0079 \\
\hline & $(2.6443)$ & $(2.5934)$ & -1.9133 & & $(0.1927)$ & (0.1988) & -0.2093 & & -0.2566 \\
\hline \multirow[t]{2}{*}{$\mathrm{C}_{\mathrm{L}}$} & $0.3268 * * *$ & $0.4925^{*}$ & 0.0433 & $\mathrm{C}_{\mathrm{L}}$ & -0.0933 & $-0.0955^{*}$ & -0.0935 & $\mathrm{r}^{\mathrm{I}}$ & $2.1266^{* *}$ \\
\hline & $(0.1255)$ & $(0.2527)$ & -0.1275 & & $(0.0742)$ & $(0.0755)$ & -0.0701 & & -0.9518 \\
\hline \multirow[t]{2}{*}{$\mathrm{K} / \mathrm{A} 1 \cdot \mathrm{C}_{\mathrm{L}}$} & $-3.8081 * * *$ & $-3.4879 * *$ & -0.9047 & $\mathrm{C}_{\mathrm{D}}$ & $0.3265^{* *}$ & $0.3224 * *$ & $0.3269^{* *}$ & & \\
\hline & (1.2878) & $(1.6672)$ & -1.0755 & & $(0.1617)$ & $(0.1600)$ & -0.1634 & & \\
\hline \multirow[t]{2}{*}{$\mathrm{C}_{\mathrm{D}}$} & 0.3244 & $0.9746^{* *}$ & $0.5780 * *$ & $\mathrm{r}^{\mathrm{K}}$ & $0.1836^{* *}$ & $0.1866 * *$ & $0.1897 * *$ & & \\
\hline & $(0.2693)$ & $(0.3990)$ & -0.2358 & & $(0.0864)$ & $(0.0863)$ & -0.0897 & & \\
\hline \multirow[t]{2}{*}{$\mathrm{K} / \mathrm{A} 1 \cdot \mathrm{C}_{\mathrm{D}}$} & -2.5643 & $-5.1730^{*}$ & -3.0416 & ln Assets & $-0.0151 * * *$ & $-0.0153 * * *$ & $-0.0153 * * *$ & & \\
\hline & (2.7574) & (2.6795) & -2.0038 & & $(0.0039)$ & $(0.0042)$ & -0.0042 & & \\
\hline \multirow[t]{2}{*}{ ln Assets } & 0.0393 & $0.0638^{* *}$ & $0.0477^{*}$ & GDP & 0.0018 & 0.0022 & 0.0015 & & \\
\hline & $(0.0254)$ & $(0.0283)$ & -0.0265 & & $(0.0066)$ & $(0.0073)$ & -0.0067 & & \\
\hline \multirow[t]{4}{*}{ ln Assets ${ }^{2}$} & -0.0011 & $-0.0017 * *$ & $-0.0013 *$ & INF & -0.0039 & -0.0041 & -0.0039 & & \\
\hline & $(0.0007)$ & $(0.0008)$ & -0.0007 & & $(0.0332)$ & $(0.0336)$ & -0.0343 & & \\
\hline & & & & $\mathrm{r}^{\mathrm{I}}$ & 0.0385 & 0.0371 & 0.0405 & & \\
\hline & & & & & $(0.1240)$ & $(0.1303)$ & -0.1327 & & \\
\hline F-test & 2039.03 & 997.47 & 3011.59 & F-test & 467.74 & 429.07 & 452.71 & F-test & 1.679 .32 \\
\hline Prob. & 0 & 0 & 0 & Prob. & 0 & 0 & 0 & Prob & 0 \\
\hline $\mathrm{R}^{2}$ & 0.783 & 0.6384 & 0.842 & $\mathrm{R}^{2}$ & 0.6448 & 0.6442 & 0.6489 & $\mathrm{R}^{2}$ & 0.9594 \\
\hline
\end{tabular}

Note: $K / A$ denotes equity/assets ratio on period $t, C A R$ denotes capital adequacy ratio, TIER 1 denotes Tier-1 capital ratio, $r^{L}$ denotes bank's lending rate, $\ln$ Loans denotes natural logarithm of total loans, $(\Delta K / A)_{t-1}$ denotes equity/assets ratio on period $t-1, r^{D}$ denotes bank's cost of fund, $C_{L}$ denotes non-performing loans, $C_{D}$ denotes other cost ratio, $r^{K}$ denotes cost of capital (ROE), ln Assets denotes natural logarithm of Total Assets, GDP denotes real GDP growth, INF denotes inflation rate, and $r^{I}$ denotes country's policy rate. Source: authors' calculations.

Another variable that showed a high level of significance $(\alpha=1 \%)$ is $\$ C \_L \$$, which is a proxy for credit risk is indicated by the non-performing loan (NPL). On models using proxy capital Equityto-Assets (KA), any increase in NPL by $10 \%$ will be raising the level of capital by $3.27 \%$. Credit risk is one of three main risk of banks that have been priority since Basel I. Capital function as bank's reserve in case of risk events, so that any additional exposure credit risk, the bank will increase its capital reserves. By using standardized approach (SA), each asset will be counted by their risk weights so any additions in NPL will increase the amount of bank risk-weighted assets. To keep capital ratios at the minimum level of $8 \%$, any increase in risk-weighted assets will be accompanied with the addition of capital, of which high capital leverage will encourage the risktaking behavior to generate a high return (see Chaibi and Ftiti, 2015).

An increase in credit risk $\left(\mathrm{C}_{\mathrm{L}}\right)$ will decrease the optimal future loans and ultimately the level of capital on hold at current time. Following the credit risk, other significant variables at $\alpha=5 \%$ are deposits interest rate $\left(\mathrm{r}^{\mathrm{D}}\right)$, other costs rate $\left(\mathrm{C}_{\mathrm{D}}\right)$ as well as total assets as shown on the model using CAR as dependent variable. Deposits interest rate and bank size have negative 
correlations with the level of capital, while other costs variable have a positive relationship. Based on data from the ASEAN-5, any increase in deposits interest rates by $1 \%$ will lower capital level by $0.80 \%$. Whilst any increase in other cost by $1 \%$ will reduce the level of capital by $0.97 \%$. Deposits interest rate and cost together with NPL (credit risk), reflecting cost of optimal future loans amount, hence rising costs will lower the optimal loans amount and ultimately the level of capital being held today. Finally, total asset which is a proxy of bank size, in this study represented by variable $\ln$ Assets. An increase total assets of $1 \%$ would raise the level of capital of $0.06 \%$, this was in line with higher bank size reflecting high capacity (equity). It can be seen that there is a non-linear relationship between bank capital and its assets indicated by $\ln$ Assets $^{2}$.

In the estimation of loan interest rates as dependent variable, an increase in deposits interest rate by $10 \%$ would raise lending rate by $10.59 \%$ and any increase in cost rate by $10 \%$ would raise lending rate by $3.27 \%$. Deposits interest rate $\left(\mathrm{r}^{\mathrm{D}}\right)$ consist of the costs incurred by the bank in the process of raising funds from public, to then be distributed in the form of loans. Hence, deposit interest rate is the principal price of bank lending interest rates, as well as other costs rate of which a reflection of the bank's operational costs. The following variable, cost of capital $\mathrm{r}^{\mathrm{K}}$ represented by return on equity (ROE), which means the expected rate of return from the banks' equity value. Achieving high return, banks require to obtain higher income from its main business, of which lending. This makes the higher the required ROE will encourage banks to raise their lending rate. As shown in this study any increase in cost of capital by $10 \%$ will be raising lending rate by $1.84 \%$.

On the balance sheet side, $\ln$ Assets is a proxy variable of bank size, which also denotes the magnitude of bank's ability to extend loans. The bigger the bank's assets the greater the ability of banks to extend loans to the public. As the law of demand, more loans quantity in the economy will decrease the price of loans, of which lending interest rate. Each increase in bank's total assets by $1 \%$ would lower lending interest rate by $0.02 \%$. This study also found that relationship between central banks' policy rate and bank lending rate are proven insignificant. These results have been described in Illes et al. (2015) studied reasons why movements in banks' lending rates different with its country's policy rate especially after the crisis. There are three main arguments: (1) policy rate is rather a short-term benchmark rate when compared with a longer tenor of bank loans; (2) banks did not acquire funding at the price of central bank interest rate; and (3) banks tends to face higher funding cost in post-crisis period.

On the last model, the study attempted to predict banks loans amount of which the results are shown in Table 5. The loans model resulted in variable $\mathrm{r}^{\mathrm{I}}$ and $\ln$ Assets having a positive relationship; while the relationship between $\mathrm{r}^{\mathrm{L}}$ and GDP is at the opposite. Any increase in banks' lending rate by $10 \%$ will decrease loans amount by $1.38 \%$. This variable is a representation of the loans price, so the higher the price the lower the amount of loans disbursed due to declining demand from the public towards loans. Whilst as proxy of bank size, any increase in total assets by $1 \%$ will increase the loans amount by $1.10 \%$. Total assets represent the ability of banks to extend its loans, or it can be said the reserve amount of funds that can be channeled as loans.

This study aimed to look at the impact of the increase in bank capital levels happened facing the economy through lending interest rates and the amount of loans being disbursed into the economy. Thus, resulted on insignificant relationship between the level of capital and Southeast 
Asian banks' lending rates. Any increase or decrease in the banks level of capital will not affect banks' behavior in determining lending interest rates, which at a later stage also will not affect the amount of loans disbursed. Lending rate determinants Southeast Asian banks are influenced by the banks' cost structure itself.

This study found that an increase in real GDP growth by $10 \%$ would have an impact on a decrease in the banks' loans by $2.65 \%$. Real GDP growth can be associated with country purchasing power, so the higher the real GDP growth the ability or the purchasing power of the people is also increasing. In this condition society no longer ask for loans, so the loans amount is reduced. The negative results can also mean that even though Real GDP growth is slowed down or show negative figures, but loans in the economy continues to increase. This condition occurs in Singapore and Thailand after the 2008 crisis. Another macroeconomic variable that affect the loans amount is $\mathrm{r}^{\mathrm{I}}$. An increase in the policy rate by $1 \%$ would increase the loans amount by $2.13 \%$. Policy rates are the interest rate used for the overnight transactions both interbank and between banks and central banks. The rising overnight rate would encourage banks actively increase lending to other banks.

\section{Conclusion}

ASEAN-5 banks characteristics are different from US and Europe banks, which lead to different results regarding the impact of the bank's capital increase. This study found that the impact of Basel III implementation in 2016 on the economy of ASEAN-5 is different when being compared to US and European banks. The finding showed that the increase level of capital does not significantly affect lending rates, which indicates that there is no need for the banks in ASEAN-5 to adjust their interest rates. Banking industry should focus on maintaining efficiency on the cost structure so that the margin obtained from the activities of financial intermediaries increased. The loans amount is not affected significantly which means the economy will tend to be stable after the implementation of Basel III regulations. Regulators can optimally utilize these rules as strengthening the stability of the financial system without any negative effects on economy. Therefore, the regulators in each country should provide sets of derivative regulations as a reference to facilitate adjustment phases of Basel III.

\section{References}

Bank for International Settlements (2011). Basel III: A global regulatory framework for more resilient banks and banking systems. Retrieved from http://www.bis.org/publ/bcbs189_ dec2010.pdf (accessed on 10 January 2015).

Barajas, A., Chami, T., Cosimano, T. F., and Hakura, D. S. (2010). U.S. bank behaviour in the wake of the 2007-2009 financial crisis. IMF Working Paper No. 10/131.

Berrios, M. R. (2013). The relationship between bank credit risk and protability and liquidity. The International Journal of Business and Finance Research, 7, 105-118.

Chaibi, H. and Ftiti, Z. (2015). Credit risk determinants: Evidence from a cross-country study. Research in International Business and Finance, 33, 1-16. 
Cosimano, T. F. and Hakura, D. S. (2011). Bank behaviour in response to Basel III: A crosscountry analysis. IMF Working Paper No. 11/119.

Forbes (2014). The world's biggest public companies. Retrieved from http://www.forbes.com/ global2000/ (accessed on 10 January 2015).

Gavalas, D. (2015). How do banks perform under Basel III? Tracing lending rates and loan quantity. Journal of Economics and Business, 81, 21-37.

Hellman, T. F., Murdock, K. C., and Stiglitz, J. E. (2000). Liberalization, moral hazard in banking, and prudential regulation: Are capital requirements enough? The American Economic Review, 90, 147-165.

Illes, A., Lombardi, M., and Mizen, P. (2015). Why did bank lending rates diverge from policy rates after the financial crisis? BIS Working Papers No 486.

Macroeconomic Assessment Group (2010). Assessing the macroeconomic impact of the transition to stronger capital and liquidity requirements. Report of Bank for International Settlement.

Raharjo, P. G., Hakim, D. B., Manurung, A. H., and Maulana, T. N. (2014). The determinant of commercial banks' net interest margin in Indonesia: An analysis of fixed effect panel regression. International Journal of Economics and Financial Issues, 4, 295-308.

Roger, S. and Vlcek, J. (2011). Macroeconomic cost of higher bank capital and liquidity requirements. Working Paper WP/11/103.

Sútorová, B. and Téply, P. (2013). The impact of Basel III on lending rates of EU banks. Finance a úvér-Czech Journal of Economics and Finance, 63, 226-243. 